\title{
The Effects of Organic Matter Amendments on Greenhouse Gas Emissions from a Mitigation Wetland in Virginia's Coastal Plain
}

\author{
R. Scott Winton ${ }^{1}$ - Curtis J. Richardson ${ }^{1}$
}

Received: 23 December 2014 / Accepted: 17 June 2015 / Published online: 3 July 2015

(C) Society of Wetland Scientists 2015

\begin{abstract}
There is concern that widespread restoration and/or creation of freshwater wetlands may present a radiative forcing hazard because of the potential for methane $\left(\mathrm{CH}_{4}\right)$ emissions. Yet data on greenhouse gas (GHG) emissions from restored wetlands are sparse and there has been little investigation into the GHG effects of amending wetland soils with organic matter $(\mathrm{OM})$, a practice used to improve function of mitigation wetlands in the Eastern United States. In this study we measure GHG emissions across an OM gradient at the Charles City Wetland (CCW) in Charles City County, Virginia. We found soils heavily loaded with $\mathrm{OM}$ emit significantly more $\mathrm{CO}_{2}$ than those that have received little or no $\mathrm{OM} . \mathrm{CH}_{4}$ emissions from $\mathrm{CCW}$ are low compared to reference wetlands and show no relationship with the loading rate of added OM or total soil carbon. We conclude that adding moderate amounts $\left(<\sim 150 \mathrm{~kg} \mathrm{~m}^{-2}\right)$ of OM to the CCW does not greatly increase GHG emissions, while the addition of high amounts of $\mathrm{OM}$ produces additional $\mathrm{CO}_{2}$, but not $\mathrm{CH}_{4} \cdot \mathrm{CH}_{4}$ flux is highest under flooded conditions during warmer months but it still a modest contribution to global warming potential compared to soil $\mathrm{CO}_{2}$ flux.
\end{abstract}

Keywords Methane - Greenhouse gas - Restoration · Soil organic matter

R. Scott Winton

scott.winton@gmail.com

1 Nicholas School of the Environment, Duke University, Durham, NC 27708, USA

\section{Introduction}

Despite making up only five to eight percent of world land cover (Mitsch and Gosselink 2007), wetland ecosystems play an important role in regulating the Earth's climate. Wetland soils contain 16 to $33 \%$ of the earth's soil carbon (C) pool of 2,500 Pg (Lal 2005; Bridgham et al. 2006) and emit 20 to $40 \%$ of methane $\left(\mathrm{CH}_{4}\right)$ (Bloom et al. 2010), an important greenhouse gas (GHG) (Myhre et al. 2013).

A review of North American wetland $\mathrm{C}$ exchange found that because of $\mathrm{CH}_{4}$ emissions, most wetlands emit more GHG than they sequester on century timescales and therefore: "...that creating and restoring wetlands may increase net radiative forcing..." (Bridgham et al. 2006). Others have claimed that because wetlands are sustainable ecosystems and persistent as $\mathrm{C}$ sinks, the widely-used 100-year time horizon is too short, and that: "...wetlands can be created and restored to provide $\mathrm{C}$ sequestration and other ecosystem services without great concern of creating net radiative sources on the climate due to methane emissions" (Mitsch et al. 2013). But errors in both the math and reasoning underpinning this latter view have been exposed (Bridgham et al. 2014; Neubauer 2014), which reaffirms the potential century-scale impact of restored and created wetland $\mathrm{CH}_{4}$ emissions on regional climate budgets.

While this controversy over the $\mathrm{C}$ balance of wetland restoration and creation is partly a disagreement about the appropriate use and calculation of global warming potential, versus sustained flux models, which account for annual pulses of GHGs (i.e., Frolking et al. 2006; Neubauer 2014), it also reflects the great uncertainty $(100 \%)$ around wetland GHG flux estimates (Bridgham et al. 2006). It thus may be particularly difficult to make long-term assumptions regarding restored and created wetland GHG fluxes given their complex histories of human disturbance and intervention and that they routinely 
fail to achieve the same ecological function of reference ecosystems over short timescales (Zedler and Callaway 1999). An important remaining question is whether created or restored freshwater wetlands with mineral soils are in fact a sink or source of GHG over policy-relevant timescales?

In the eastern United States large areas of freshwater wetlands are created or restored as part of compensatory mitigation mandated by section 404 of the Clean Water Act, and they commonly suffer from an initial deficiency of soil organic matter (OM) (Stauffer and Brooks 1997; Whittecar and Daniels 1999) compared to natural wetlands (Bailey et al. 2007). Many studies have advocated for the amendment of created wetlands with $\mathrm{OM}$ in the form of salvaged topsoil or compost to help them achieve reference functionality (Stauffer and Brooks 1997; Whittecar and Daniels 1999; Bruland and Richardson 2004). Indeed, studies have found that moderate loading of compost OM into a created wetland increase woody plant development (Bailey et al. 2007) and soil functions, such as microbial decomposition and increased denitrification enzyme activity (Bruland and Richardson 2009; Sutton-Grier et al. 2009).

Few studies have measured GHG emissions from created or restored wetlands and fewer still have done so at sites amended with OM. It is unclear whether or not the practice of adding OM to created wetlands will have an effect on their radiative impact, though one study at a freshwater tidal wetland in Virginia may provide a clue. In this case wetland soil cores, when amended with leaf litter $\mathrm{OM}$, tended to produce more $\mathrm{CH}_{4}$ and $\mathrm{CO}_{2}$ over unamended controls, while soils amended with compost $\mathrm{OM}$ produced more $\mathrm{CO}_{2}$, but no additional $\mathrm{CH}_{4}$ (Morrissey et al. 2013). These findings are compelling, but need to be replicated at an independent site and confirmed in situ.

The purpose of this study is to investigate how a gradient of added compost OM affects GHG emissions from a created mitigation wetland. Included in our analysis is an estimate of how long it would take for our restored wetland to change from a GHG source to a sink, calculated as the radiative forcing switchover time following Frolking et al. (2006).

\section{Methods}

\section{Site Description}

The study took place within the 20.8-ha Charles City Wetland Mitigation Site $(\mathrm{CCW})$, which is located in Charles City County, Virginia, USA $\left(37^{\circ} 20^{\prime} 37^{\prime} \mathrm{N}, 76^{\circ} 55^{\prime} 33^{\prime \prime} \mathrm{W}\right)$, and owned by the Virginia Department of Transportation (VDOT) as part of its compensatory mitigation program (Bailey et al. 2007). Precipitation is the dominant hydrologic input and the CCW may hold up to $0.5 \mathrm{~m}$ of standing water during cooler months (Bailey et al. 2007). Site history is described in detail by Bergschneider (2005) and Bailey et al. (2007), but briefly summarized here. Prior to restoration the site was covered by upland mixed hardwood forest that had been partially converted to agricultural field. The soil was mapped as a complex of Chickahominy (fine, mixed, semiactive, thermic Typic Endoaquults) and Newflat (fine, mixed, subactive, thermic Aeric Endoaquults) series (Bergschneider 2005). Mitigation efforts attempted to convert field and remnant forest to wetland status during the winter of 1997-1998 by excavating into the subsoil (E or Btg horizon) to the depth of the presumed seasonal high water table. After revegetation, many parts of the site were found to be covered in facultative or upland plant species with much less hydrophytic cover than desired for mitigation purposes, a result attributed to restoration activities in which topsoil was lost, leaving compacted, low organic matter $(\mathrm{OM})$ subsoil at the surface. The addition of an OM source had been proposed as a method for improving function of mitigation wetlands (Stauffer and Brooks 1997), but no data existed regarding the quantity of added OM required to achieve sufficiently improved wetland function in this setting. With a goal of determining optimal OM amendment loads for the wetland, a research group from Virginia Polytechnic Institute and State University implemented a gradient experiment in 2001 with 4 replicate plots of $4 \mathrm{OM}$ loading rates (plus control) in an experimental block. Municipal wood and yard waste compost was rototilled into the topsoil of 4.6 by $3.1 \mathrm{~m}$ plots at loading rates of 56, 112, 224 and $336 \mathrm{~kg} \mathrm{~m}^{-2}$ (dry weight) in July, 2002. Control plots received only rototilling. Each plot was planted with five Pin Oak (Quercus palustris) and River Birch (Betula nigra) saplings, but otherwise the site was allowed to revegetate naturally from seed bank. In January, 2013 we found a mean count of 3.4 Q. palustris and 4.6 B. nigra survived in each $14.3 \mathrm{~m}^{2}$ plot with some volunteer tree species, such as Red Maple (Acer rubrum) and Black Willow (Salix nigra), established sporadically.

\section{Site Characterization}

We measured the relative elevation of each plot near the gas collars used for measuring GHGs using a Topcon RL-H3A laser level and collected soil cores in each plot in September, 2011 using a 10-cm diameter soil-corer. Cores were split into 0 to 5 and 5 to $10 \mathrm{~cm}$ depth sections in the field. In the lab each core section was weighed wet and a subsample was weighed, oven-dried and re-weighed to estimate wet:dry ratios and calculate bulk density. Subsamples were analyzed for total carbon $(\mathrm{C})$ and total $(\mathrm{N})$ using a CE Instruments Flash Elemental Analyzer. We sampled soils again in September, 2012 using a punch tube and separated depth sections of 0 to $2 \mathrm{~cm}, 4$ to 6,9 to 11 and 19 to $21 \mathrm{~cm}$ in the field, and then composited corresponding depths from three replicate punches. These soils were analyzed for total $\mathrm{C}$, total $\mathrm{N}$ (following the same method as above), digested following a nitric-perchloric acid method followed by colorimetric analysis of total phosphorus (P) 
using a Beckman DU-64 spectrophotometer, Meilich-3extractable $\mathrm{P}, \mathrm{KCl}$-extractable nitrate/nitrite $\left(\mathrm{NO}_{\mathrm{x}}\right)$ and ammonia/ammonium $\left(\mathrm{NH}_{\mathrm{x}}\right)$ using a Lachat Quickchem 8000 autoanalyzer. We installed litter fall traps (approximately $1000 \mathrm{~cm}^{2}$ ) in each plot in September, 2012 and litter was collected during subsequent site visits.

\section{Greenhouse Gas Sampling}

We installed one 20-cm diameter PVC collar 10 to $15 \mathrm{~cm}$ into the soil in each plot for static chamber GHG gas sampling (Livingston and Hutchinson 1995; Weishampel and Kolka 2008) in fall 2011. After observing that the close approach necessary for setup and sampling of PVC collars was generating unreliable $\mathrm{CH}_{4}$ data due to soil disturbance, we redeployed $30-\mathrm{cm}$ diameter static chamber collars affixed with a waterfillable gutter in the spring of 2012. To avoid soil disturbance and improve $\mathrm{CH}_{4}$ data quality, we used a remote rod sampling system, which allows chambers to be set up and sampled from a distance of $2 \mathrm{~m}$ (Winton and Richardson, in review) for subsequent trace gas sampling every 2 months from May, 2012 until January, 2013. We excluded from analysis unreliable $\mathrm{CH}_{4}$ data generated by the original PVC collars, but include complete, unimpacted $\mathrm{CO}_{2}$ data collected from these collars on October 2011 and February 2012. Sampling errors on September 12, 2012 impacted a large portion of $\mathrm{CH}_{4}$ flux data, so we repeated measurements on September 26 for $\mathrm{CH}_{4}$ analysis. $\mathrm{CO}_{2}$ results were not affected and we averaged results from both September, 2012 dates for subsequent analysis.

Static chambers were opaque and total extracted gas volume was never greater than $5 \%$ of chamber headspace. We left any plants growing within chamber footprints intact unless they were long enough to interfere with chamber setup, in which case we clipped them. On each sampling date we collected headspace gas four times over the course of half-hour incubations from collars in each of the 20 plots. Following placement of the static chamber top on the collar we immediately extracted a $50-\mathrm{ml}$ headspace sample via a plastic syringe and deposited it into a mylar gas-tight sample bag. We recorded ambient air temperature (T), internal chamber $\mathrm{T}$, soil $\mathrm{T}$ at $5 \mathrm{~cm}$ depth for initial and subsequent samples taken approximately 5, 15 and $30 \mathrm{~min}$ following chamber setup. We transported gas bags to the Duke University Wetland Center laboratory and analyzed within 1 week of collection on a Varian 450 Gas Chromatograph (GC) equipped with a flame ionization detector and methanizer to analyze $\mathrm{CH}_{4}$ and $\mathrm{CO}_{2}$ concentrations synchronously. All samples were run in duplicate with the mean value used for gas flux calculations unless duplicate values differed by $>10 \%$, in which case the obviously outlying value was assumed to stem from analytical error and discarded. Flux was estimated by linear regression of sample concentrations as a function of time elapsed. If a threshold r-squared value of 0.90 was not met, we removed one outlying point if it improved fit to $>0.90$ (approximately $5 \%$ of incubations), otherwise such estimates were treated as failed incubations and discarded. We estimate the minimum detectable flux for $\mathrm{CO}_{2}$ was $52 \mathrm{mg} \mathrm{m}^{-2} \mathrm{~h}^{-1}$ and for $\mathrm{CH}_{4}$ was $0.037 \mathrm{mg} \mathrm{CH}_{4} \mathrm{~m}^{-2} \mathrm{~h}^{-1}$. We analyzed all samples for nitrous oxide, but found flux to be below minimum detection thresholds for approximately $90 \%$ of incubations, so we focus our results and discussion on $\mathrm{CH}_{4}$ and $\mathrm{CO}_{2}$.

\section{Hydrologic Data}

We measured soil volumetric water content (SVWC) in the top $5 \mathrm{~cm}$ using a Fieldscout 100 time domain reflectometry probe (Spectrum Technologies) starting in May, 2012. We recorded the mean of five measurements taken adjacent to each chamber collar. We installed five Odyssey loggers (Dataflow Systems, Christchurch, New Zealand), which monitored water level hourly starting in February 2012. We collected daily rainfall and air $\mathrm{T}$ data from nearby meteorological stations in Williamsburg and Norfolk, Virginia, which are publicly accessible via the National Climatic Data Center (Lawrimore et al. 2011).

\section{Statistical Analyses}

We used ANOVA and Tukey's honest significant difference test to test for differences in gas flux between groups of plots with different $\mathrm{OM}$ treatments and linear regression to look for trends in gas flux across the OM gradient. We evaluated all data for normality by generating box-and-whisker, histogram and quantile-quantile plots and log-transformed data when necessary. We explored relationships between gas flux and potential explanatory variables using the Ecodist package (Goslee and Urban 2007) and by building generalized linear models (GLM). We used these models to estimate daily emissions of $\mathrm{CO}_{2}$ and $\mathrm{CH}_{4}$ and generate an annual flux budget from March 1, 2012 to February 28, 2013. We used JMP Pro 11 (SAS Institute Inc 2013) to plot GLM outputs. All other statistics were computed using the R programming language (R Core Team 2014) and in Microsoft Excel 2010.

\section{Carbon Balance}

We compare the relative radiative impacts of soil $\mathrm{CH}_{4}$ and $\mathrm{CO}_{2}$ fluxes by multiplying $\mathrm{CH}_{4}$ by its 100 -year sustained global warming potential of 45 (Neubauer and Megonigal 2015). We estimate radiative forcing switchover time, determined by the ratio of $\mathrm{CO}_{2}$ stored : $\mathrm{CH}_{4}$ emitted, (Frolking et al. 2006) for the CCW by assuming annual net ecosystem exchange (NEE) estimates (Bailey 2006) and annual $\mathrm{CH}_{4}$ flux estimates generated in this study will be sustained over centuries. Bailey (2006) found NEE to be negative (net emission of $\mathrm{CO}_{2}$ ) for most of the $\mathrm{CCW}$ plots because of rapid oxidation of 
added OM early in the experiment, therefore we only used his positive mean NEE values (net uptake of $\mathrm{CO}_{2}$ ) from the lowest loading rates (141.1 and $29.9 \mathrm{~g} \mathrm{CO}_{2}-\mathrm{C} \mathrm{m}^{-2} \mathrm{y}^{-1}$ ) to generate a range of potential radiative forcing switchover times.

\section{Results}

\section{GHG Fluxes}

$\mathrm{CO}_{2}$ Flux

We observed the highest $\mathrm{CO}_{2}$ fluxes ( $>400 \mathrm{mg} \mathrm{m}^{-2} \mathrm{~h}^{-1}$ ) during warmer, drier months and these contrast with fluxes approaching minimum analytical detection limits during cold, wet months (Fig. 1). $\mathrm{CO}_{2}$ emissions from soil directly responded to increases in soil $\mathrm{T}$ (Fig. 2) and in general, the higher $\mathrm{CO}_{2}$ emissions are associated with higher OM loading rates; linear regression of log-transformed $\mathrm{CO}_{2}$ flux as a function of OM treatment shows significant positive relationships across all sampling months except September (Table 1). The relationship between $\mathrm{OM}$ and $\mathrm{CO}_{2}$ emission is strongest during peak flux in July which is one of only 2 months (the other being January) where significant differences in $\mathrm{CO}_{2}$ flux between OM treatments occur.

A GLM with three parameters: soil $\mathrm{T}$ (coefficient $=0.058$; $p<0.001$ ), soil volumetric water content (SVWC; coefficient $=-0.025 ; p<0.001$ ), and surface soil total C (coefficient $=0.031 ; p<0.001$ ), explains much of the variability $\left(\mathrm{r}^{2}=0.75\right)$ in log-transformed $\mathrm{CO}_{2}$ flux across all sampling dates (Fig. 3a). Soil T and SVWC are the two most important terms in our GLM explaining log-transformed $\mathrm{CO}_{2}$ flux variability across seasons, with r-squared values of 0.50 and 0.49 respectively. Soil T and SVWC are correlated with each other (r-squared of 0.40), but this relationship is driven by one sampling date in July when the site was both very warm and very dry. Including both soil $\mathrm{T}$ and SVWC improves model $\mathrm{r}$ - squared to 0.71 . The third model parameter, total surface soil $\mathrm{C}$ partly reflects the amount of $\mathrm{OM}$ available to be decomposed. The effects of soil $\mathrm{C}$ on $\mathrm{CO}_{2}$ flux become obvious when the site is sufficiently dry (i.e., July), but during wetter periods the importance of surface soil $\mathrm{C}$ is obscured. So while soil C is very weakly correlated with logtransformed $\mathrm{CO}_{2}$ flux across all sampling dates ( $\mathrm{r}$-squared of 0.05 ), including it in the GLM helps improve fit (r-squared of 0.75 ) and reduces the Akaike information criterion.

With $\mathrm{T}$ and soil moisture held relatively constant across the site during a given sampling date (relative to seasonal changes), we found surface soil $\mathrm{C}$ to be the most important parameter (coefficient $=25 ; p=0.001$ ) explaining $\mathrm{CO}_{2}$ flux in July ( $\mathrm{r}$ squared of 0.52 ). The inclusion of total soil $\mathrm{N}$ at $20 \mathrm{~cm}$ depth (coefficient $=3900 ; p=0.05$ ) improved our GLM r-squared to 0.63 (see Fig. 3b) and it was not highly correlated with surface soil C (r-squared of 0.24 ).

Since we do not have high frequency SVWC and soil T data, we used highly correlated water level $\left(\mathrm{r}^{2}=0.93\right)$ and mean air T from the preceding 7 days $\left(\mathrm{r}^{2}=0.98\right.$; as measured in Norfolk, Virginia; National Climatic Data Center), as respective substitutes to model daily $\mathrm{CO}_{2}$ flux from March 1, 2012 through February 28, 2013. We assume surface soil total C would remain constant over the year. From this model we estimate an annual $\mathrm{CO}_{2}$ flux ranging from 0.44 to $0.64 \mathrm{~kg} \mathrm{CO}_{2}-\mathrm{C}$ $\mathrm{m}^{-2}$ year ${ }^{-1}$ from the low to high end of the OM gradient.

\section{$\mathrm{CH}_{4}$ Flux}

We find $\mathrm{CH}_{4}$ fluxes consistently exceed minimum analytical detection only when soil $\mathrm{T}$ was at least $15{ }^{\circ} \mathrm{C}$ and some ponded water was present at the CCW (see Table 2). We identify a threshold of $50 \%$ SVWC, below which $\mathrm{CH}_{4}$ was never greater than $0.13 \mathrm{mg} \mathrm{CH}_{4} \mathrm{~m}^{-2} \mathrm{~h}^{-1}$ (Fig. 4). When conditions at the $\mathrm{CCW}$ are favorable for methanogenesis fluxes are highly variable across plots. We observed maximum $\mathrm{CH}_{4}$ fluxes of approximately 3 to $5 \mathrm{mg} \mathrm{m}^{-2} \mathrm{~h}^{-1}$ during sampling in
Fig. 1 Mean $( \pm$ SE) carbon dioxide flux from the organic matter experimental plots at the Charles City Wetland in Charles City County, Virginia across nine sampling dates from September, 2011 to January, 2013. Different dash patterns represent loading rates of organic matter in $\mathrm{kg} \mathrm{m}^{-2}$

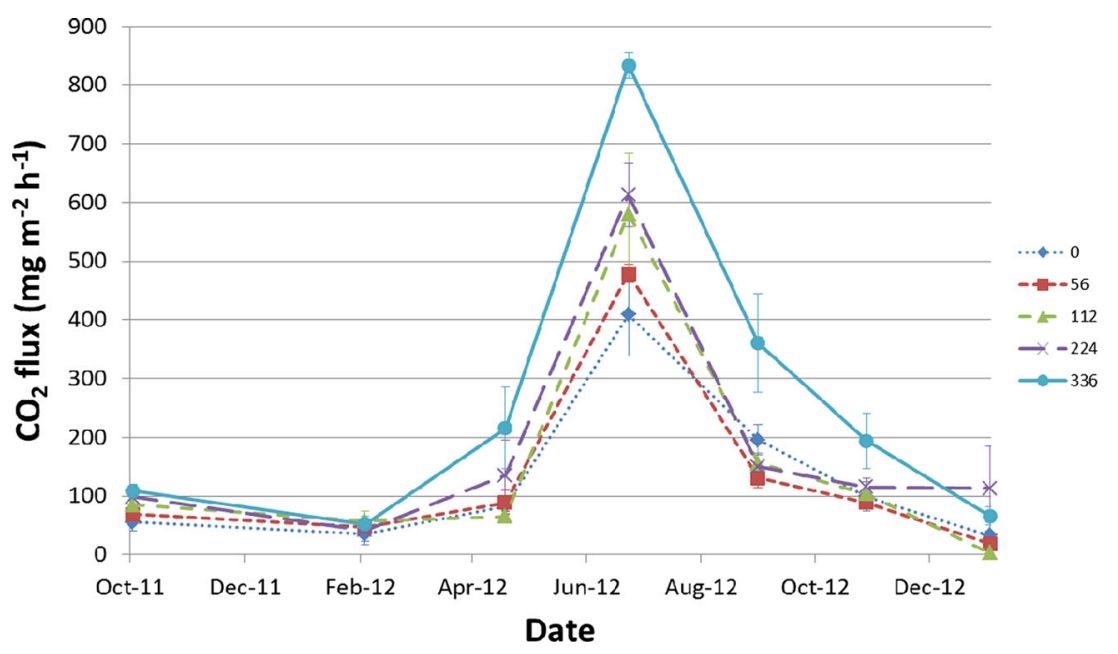


Fig. 2 Mean carbon dioxide flux from a range of organic matter treatments as a function of soil temperature at $5 \mathrm{~cm}$ depth from experimental plots at the Charles City Wetland in Charles City County, Virginia across eight sampling dates from November, 2011 to January, 2013. Error bars represent standard errors of the mean

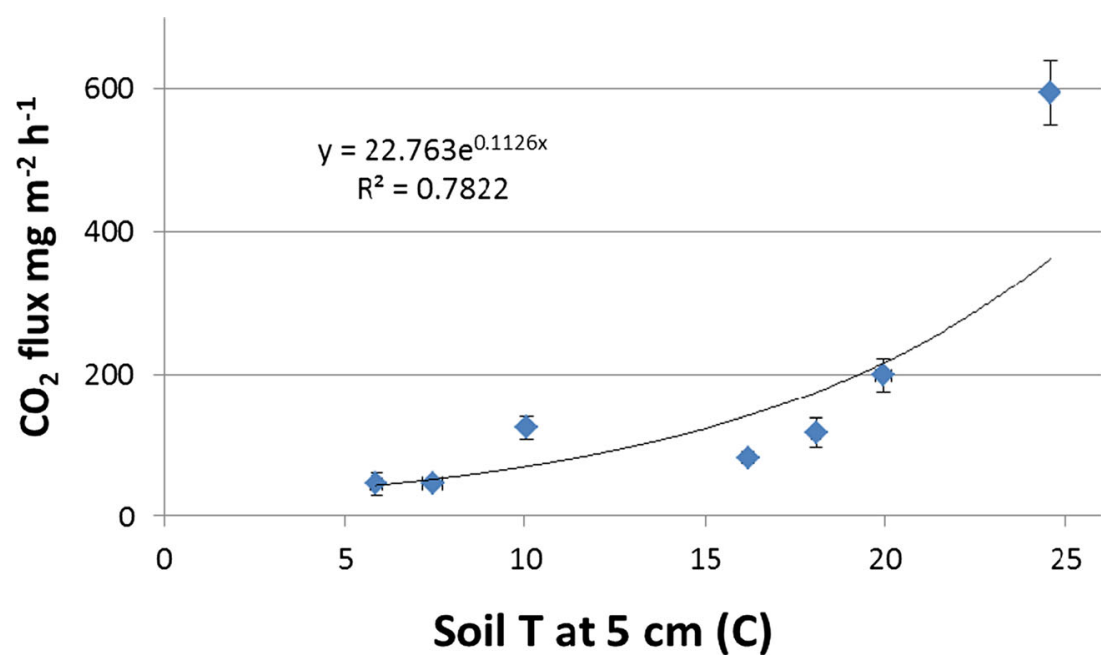

May and September 2012. But even on these high flux dates we are unable to detect any statistically significant patterns in $\mathrm{CH}_{4}$ flux related to $\mathrm{OM}$ loading rate using linear regression (May, 2012: $p=0.16$; and Sept. 2012: $p=0.21$ ) and Tukey's honest significant difference test (May, 2012: $p=0.92$; and Sept. 2012: $p=0.60$ ) when comparing the highest loading rate to control). Furthermore the non-significant linear regression coefficients were negative, with lower $\mathrm{CH}_{4}$ flux associated with greater $\mathrm{OM}$ amendment, the opposite of what would be expected if added $\mathrm{OM}$ is fueling $\mathrm{CH}_{4}$ production and emission.

To model annual $\mathrm{CH}_{4}$ flux we assume $\mathrm{CH}_{4}$ will respond in a binary fashion to soil T and SVWC based on the thresholds we identified. We imputed mean measured $\mathrm{CH}_{4}$ flux from $\mathrm{CH}_{4}$ favorable sampling dates $\left(1.1 \mathrm{mg} \mathrm{CH}_{4} \mathrm{~m}^{-2} \mathrm{~h}^{-1}\right)$ for each day during which conditions met the threshold we identified (soil $\mathrm{T}>15{ }^{\circ} \mathrm{C}$ and SVWC $>50 \%$ ). If the soil T and SVWC thresholds were not both met, we assumed $\mathrm{CH}_{4}$ flux would be equal

Table 1 Summary of linear regression and ANOVA tests for differences and trends in log-transformed carbon dioxide $\left(\mathrm{CO}_{2}\right)$ emissions between and across gradient of plots treated with different levels of organic matter (OM) at the Charles City Wetland in Charles City County, Virginia

\begin{tabular}{llll}
\hline Month & \multicolumn{2}{l}{ Linear regression } & ANOVA \\
\cline { 2 - 3 } & p-value & r-squared & p-value \\
\hline Oct., '11 & $\mathbf{0 . 0 2 1}$ & 0.22 & 0.231 \\
Feb., '12 & 0.93 & -0.05 & 0.813 \\
May, '12 & $\mathbf{0 . 0 2 8}$ & 0.24 & 0.165 \\
July, '12 & $<\mathbf{0 . 0 0 1}$ & 0.55 & $\mathbf{0 . 0 1 8}$ \\
Sept., '12 & 0.133 & 0.12 & 0.116 \\
Nov., '12 & $\mathbf{0 . 0 0 9}$ & 0.40 & 0.126 \\
Jan., '13 & $\mathbf{0 . 0 4 3}$ & 0.21 & $\mathbf{0 . 0 0 3}$ \\
\hline
\end{tabular}

Values that meet $p<0.05$ are bolded to mean measured $\mathrm{CH}_{4}$ flux from $\mathrm{CH}_{4}$-unfavorable sampling dates $\left(0.012 \mathrm{mg} \mathrm{CH}_{4} \mathrm{~m}^{-2} \mathrm{~h}^{-1}\right)$. By running this model from March 1, 2012 through February 28, 2013 we estimate an annual flux of $3.1 \mathrm{~g} \mathrm{CH}_{4}-\mathrm{C} \mathrm{m}^{-2} \mathrm{y}^{-1}$ from the CCW.

\section{Carbon Balance}

During the sampling dates when $\mathrm{CH}_{4}$ flux was large enough to be detectable (May and September), its contribution to radiative forcing was relatively minor on average (less than one-third) when compared to soil $\mathrm{CO}_{2}$ flux using a newly suggested 100 year sustained global warming potential of 45 for $\mathrm{CH}_{4}$ (Neubauer and Megonigal 2015) (Fig. 5). If we make the same comparison using our modelled annual $\mathrm{CO}_{2}$ and $\mathrm{CH}_{4}$ flux estimates we find $\mathrm{CH}_{4}$ contributes approximately 8 to $12 \%$ of the radiative forcing budget. The $\mathrm{CO}_{2}^{-}$sequestration: $\mathrm{CH}_{4}$-flux ratio of $\mathrm{CCW}$ ranges from 125 to 26 , corresponding to a radiative forcing switchover time range of less than 300 years following Neubauer's (2014) model.

\section{Hydrology and Soil Elevations}

Water level data suggest that the hydrology of CCW is controlled by precipitation inputs with storm events and dry spells driving periodic fluctuations of more than $1 \mathrm{~m}$ in the water table (Fig. 6). Ponded water was present at the site $59 \%$ of the time from 22 February, 2012 to 21 January, 2013 and reached a maximum depth of $14 \mathrm{~cm}$ above the mean elevation of unamended plots. The distribution of plot elevations is approximately normally distributed with a standard deviation of $4 \mathrm{~cm}$ and two outliers: a $12 \mathrm{~cm}$ "hummock" and a $-9 \mathrm{~cm}$ "hollow." Pairwise comparison (ANOVA) of plots grouped by OM loading rate shows no significant differences in mean elevation, though there is a weak $\left(\mathrm{r}^{2}=0.18\right)$, but significant $(p<0.05)$ positive linear trend in elevation across the OM gradient. 


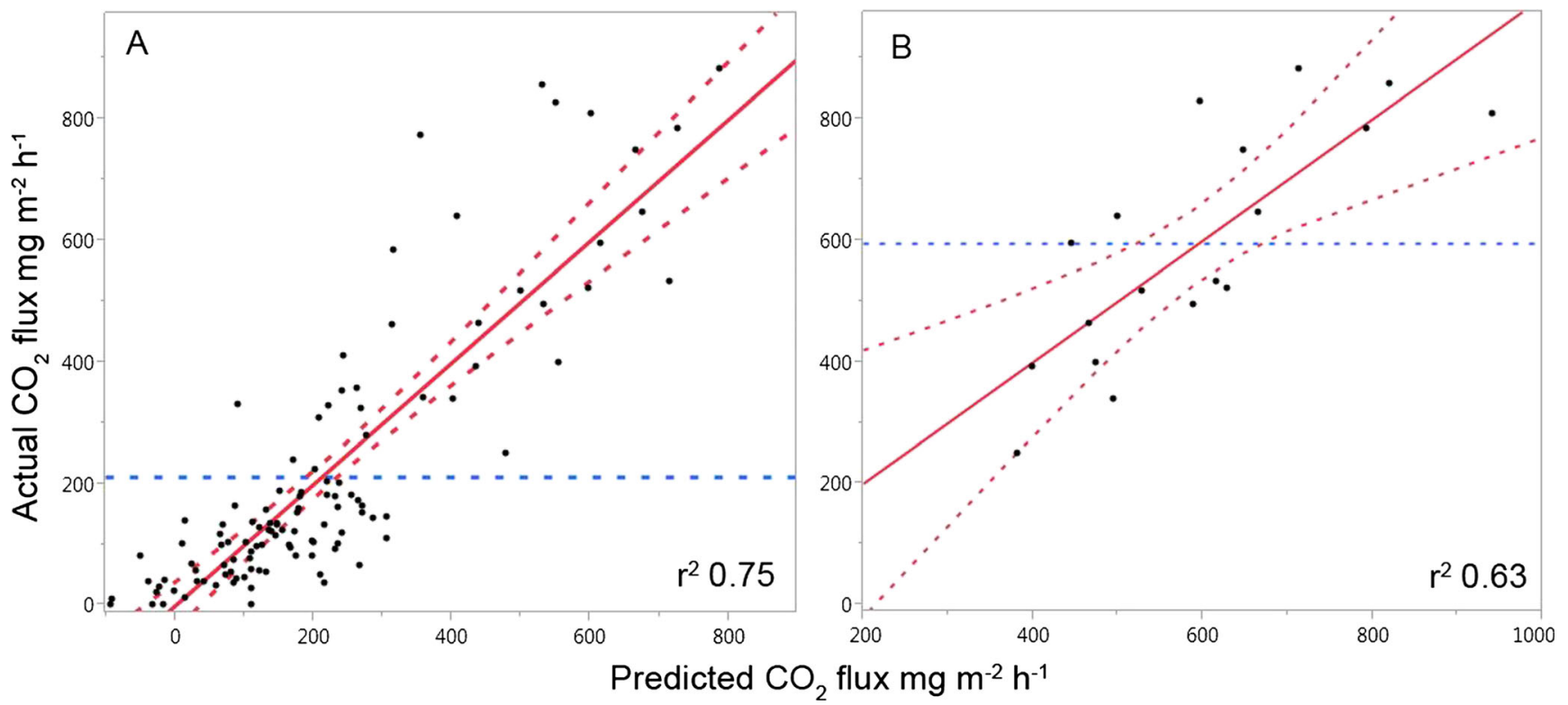

Fig. 3 Actual carbon dioxide flux compared to linear model predictions at the Charles City County Wetland in Charles City County, Virginia for: A) data across five sampling dates from May 2012 to January 2013 and multiple regression predictions based on soil temperature $(5 \mathrm{~cm}$ depth), soil volumetric water content, and total soil carbon (top $5 \mathrm{~cm}$ ); and B) data

\section{Soil Nutrients}

Total soil $\mathrm{C}$ data show that as much as $50 \%$ of the added OM has been lost since 2005 (Bailey et al. 2007), with the biggest loss observed in plots loaded with 112 and $224 \mathrm{~kg} \mathrm{~m}^{-2} \mathrm{OM}$. Nevertheless, the gradient, as originally established, persists (see Fig. 7), with total $\mathrm{C}$ in the top $10 \mathrm{~cm}$ of soil ranging from approximately 2 to $13 \%$. Mean and standard error (SE) litter fall across the plots during the fall of 2012 was $0.37 \pm$ $0.045 \mathrm{~kg} \mathrm{~m}^{-2}$, which assuming litter is $50 \% \mathrm{C}$ by weight (Bocock 1964), represents an input of $0.19 \pm 0.023 \mathrm{~kg} \mathrm{C} \mathrm{m}^{-2}$ $\mathrm{y}^{-1}$ to surface soils. Total soil $\mathrm{C}, \mathrm{N}$ and $\mathrm{P}$ are generally higher in plots that received higher loading rates of $\mathrm{OM}$, but decrease with depth such that differences between loading rates are from 22 July 2012 and linear predictions based on total soil carbon (top $5 \mathrm{~cm}$ ) and total soil nitrogen at $20 \mathrm{~cm}$ depth. Dashed curves represent $95 \%$ confidence intervals for the regression line. Dashed horizontal line indicates mean carbon dioxide flux value

negligible at 10 and $20 \mathrm{~cm}$ depth. $\mathrm{KCl}$-extractable $\mathrm{NH}_{\mathrm{x}}$ and $\mathrm{NO}_{\mathrm{x}}$ and Mehlich-3-extractable $\mathrm{P}$ follow roughly similar patterns.

\section{Discussion}

\section{Controls of Greenhouse Gas Emissions}

Wetland GHG flux at the CCW is moderated by soil T because of the temperature dependence of soil respiration (Lloyd and Taylor 1994), as well as hydrologic dynamics. Hydrology is important because saturation inhibits aerobic decomposition and creates conditions favorable for $\mathrm{CH}_{4}$ emission (Whalen
Table 2 Summary of monthly averages $( \pm \mathrm{SE})$ soil temperature (at $5 \mathrm{~cm}$ depth), hydrology and soil carbon emissions from the Charles City Wetland in Charles City County, Virginia. Methane $\left(\mathrm{CH}_{4}\right)$ values reported below our minimum detection threshold $\left(0.037 \mathrm{mg} \mathrm{m}^{-2} \mathrm{~h}^{-1}\right)$ are the results of averaging many zero fluxes with a few low values. All data collected in 2012 except for October, 2011 and January, 2013

\begin{tabular}{llllll}
\hline Month & $\begin{array}{l}\text { Soil temp. } \\
{ }^{\circ} \mathrm{C}\end{array}$ & $\begin{array}{l}\text { Water level } \\
\mathrm{cm}\end{array}$ & $\begin{array}{l}\text { Soil volumetric water content } \\
\%\end{array}$ & $\begin{array}{l}\mathrm{CH}_{4} \text { emissions } \\
\mathrm{mg} \cdot \mathrm{m}^{-2} \cdot \mathrm{h}^{-1}\end{array}$ & $\mathrm{CO}_{2}$ emissions \\
\hline Oct. & $16.2 \pm 0.2$ & $3.7 \pm 0.8^{\mathrm{a}}$ & $\mathrm{NA}^{\mathrm{b}}$ & $\mathrm{NA}^{\mathrm{c}}$ & $77 \pm 8$ \\
Feb. & $7.3 \pm 0.3$ & $5.9 \pm 0.9$ & $\mathrm{NA}^{\mathrm{b}}$ & $\mathrm{NA}^{\mathrm{b}}$ & $47 \pm 5$ \\
May & $18.1 \pm 0.1$ & $5.3 \pm 0.6$ & $65.6 \pm 1.7$ & $0.82 \pm 0.20$ & $117 \pm 21$ \\
July & $24.6 \pm 0.08$ & $-39.9 \pm 6.4$ & $29.9 \pm 2.6$ & $0.02 \pm 0.01$ & $595 \pm 43$ \\
Sept. & $20.0 \pm 0.2$ & $6.0 \pm 0.5$ & $60.2 \pm 1.0$ & $1.29 \pm 0.27$ & $188 \pm 30$ \\
Nov. & $10.1 \pm 0.09$ & $3.0 \pm 0.5$ & $55.5 \pm 1.5$ & $0.02 \pm 0.01$ & $124 \pm 14$ \\
Jan. & $5.9 \pm 0.2$ & $9.2 \pm 0.6$ & $60.5 \pm 1.4$ & 0 & $32 \pm 6$
\end{tabular}

${ }^{\mathrm{a}}$ water depth measured by hand within plots rather than in wells; may not be comparable to other data

${ }^{\mathrm{b}}$ not measured

${ }^{\mathrm{c}}$ methodological issue led to unusable $\mathrm{CH}_{4}$ data, therefore we omit from analysis. See Methods section 
Fig. 4 Methane flux $\left(\mathrm{CH}_{4}\right)$ as a function of soil volumetric water content measured from the organic matter experimental plots at the Charles City Wetland in Charles City County across five sampling dates from May 2012 to January 2013

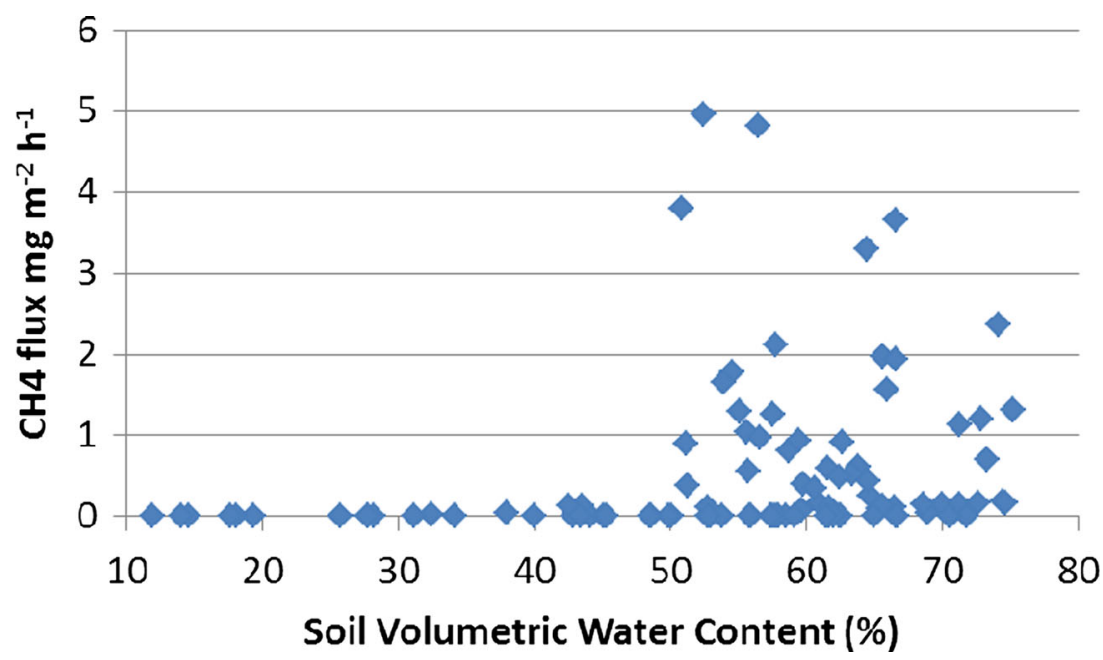

2005), as is illustrated by the soil volumetric water content threshold we identified (Fig. 4). In addition to facilitating $\mathrm{CH}_{4}$ flux, high water levels are also associated with lower rates of $\mathrm{CO}_{2}$ emission because soil respiration is typically oxygen-limited in a wetland setting. Our hydrologic data are consistent with previous work indicating that the $\mathrm{CCW}$ is a groundwater recharge system with hydrologic inputs dominated by precipitation (Despres 2004).

Related to hydrology is the elevation of surface soil. While the site has very little relief, microtopographic features $(<10 \mathrm{~cm})$ are related to $\mathrm{OM}$ loading rate and can be significant relative to water depth at the $\mathrm{CCW}$. During $\mathrm{OM}$ addition to the $\mathrm{CCW}$ in 2001 there was difficulty in completely incorporating the highest OM loading rates into plots, which led to mounding (Daniels et al. 2005). Therefore we suspected elevation might be a confounding factor in predicting GHG flux since it correlates with OM loading rate, but when we included it as a predictor of GHG fluxes in our GLM tests it did not emerge as significant. Thus we conclude that differences in elevation across the OM gradient are not driving seasonal GHG patterns.

In addition to soil $\mathrm{T}$ and hydrology, surface soil $\mathrm{C}$ also correlates with $\mathrm{CO}_{2}$ flux, which suggests that the addition of OM causes higher rates of aerobic decomposition and/or root respiration. We assume that soil $\mathrm{N}$ at depth correlates with $\mathrm{CO}_{2}$ flux because a greater $\mathrm{N}$ pool in the rooting zone should stimulate higher rates of autotrophic and heterotrophic respiration related to $\mathrm{N}$ mineralization (Schlesinger 1997).

While we were able to find some relationships between soil $\mathrm{C} / \mathrm{N}$ and $\mathrm{CO}_{2}$ flux, $\mathrm{CH}_{4}$ did not correlate with any of the soil chemical properties we measured. Hydrology and $\mathrm{T}$ both control rates of $\mathrm{CH}_{4}$ production by dictating oxygen availability and demand (Whalen 2005), which explains why we found $\mathrm{CH}_{4}$ flux to be very low during cold and/or dry periods. $\mathrm{CH}_{4}$ flux variability is consistent with results from other forested wetlands of the Southeastern US but our annual $\mathrm{CH}_{4}$ flux estimate was on the low end of the range of published estimates for analogous systems (Table 3).
Fig. 5 Carbon dioxide $\left(\mathrm{CO}_{2}\right)$ and methane $\left(\mathrm{CH}_{4}\right)$ flux from soil across five levels of organic matter loading rates estimated from sampling on 7 May and 26 September, 2012 at the Charles City Wetland in Charles City County, Virginia, USA. Note: $\mathrm{CH}_{4}$ was converted to $\mathrm{CO}_{2}-$ equivalents by multiplying by 45 - its 100-year sustained global warming potential following Neubauer and Megonigal (2015). Error bars represent standard errors of the mean

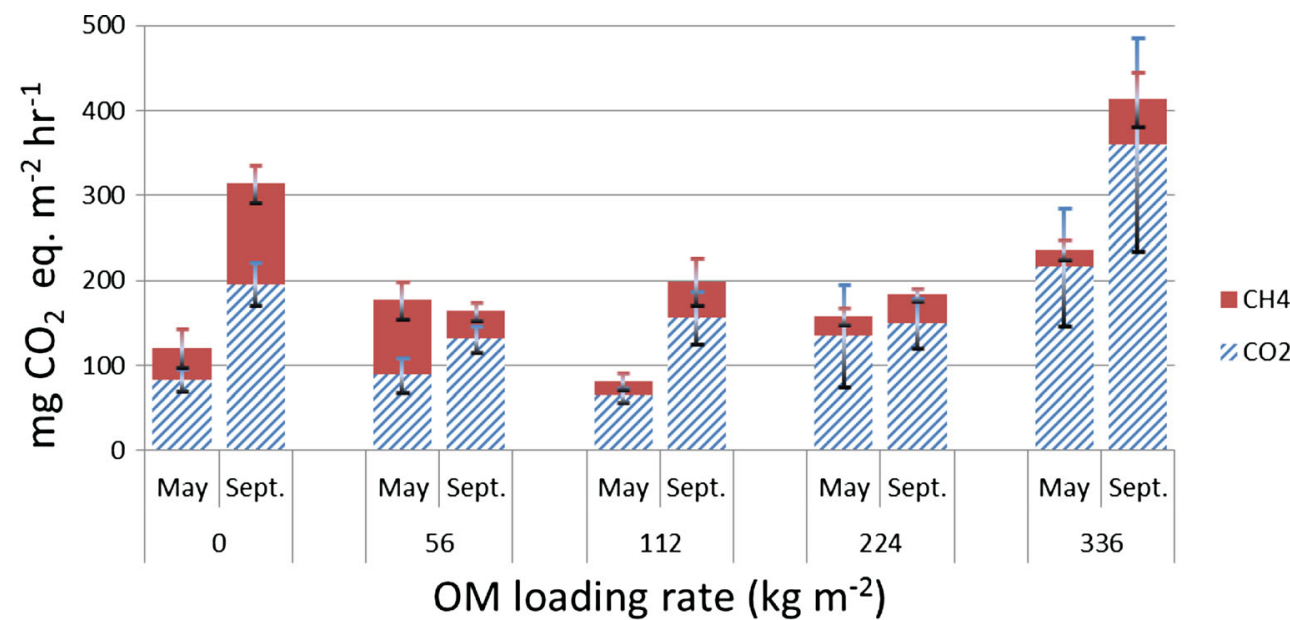




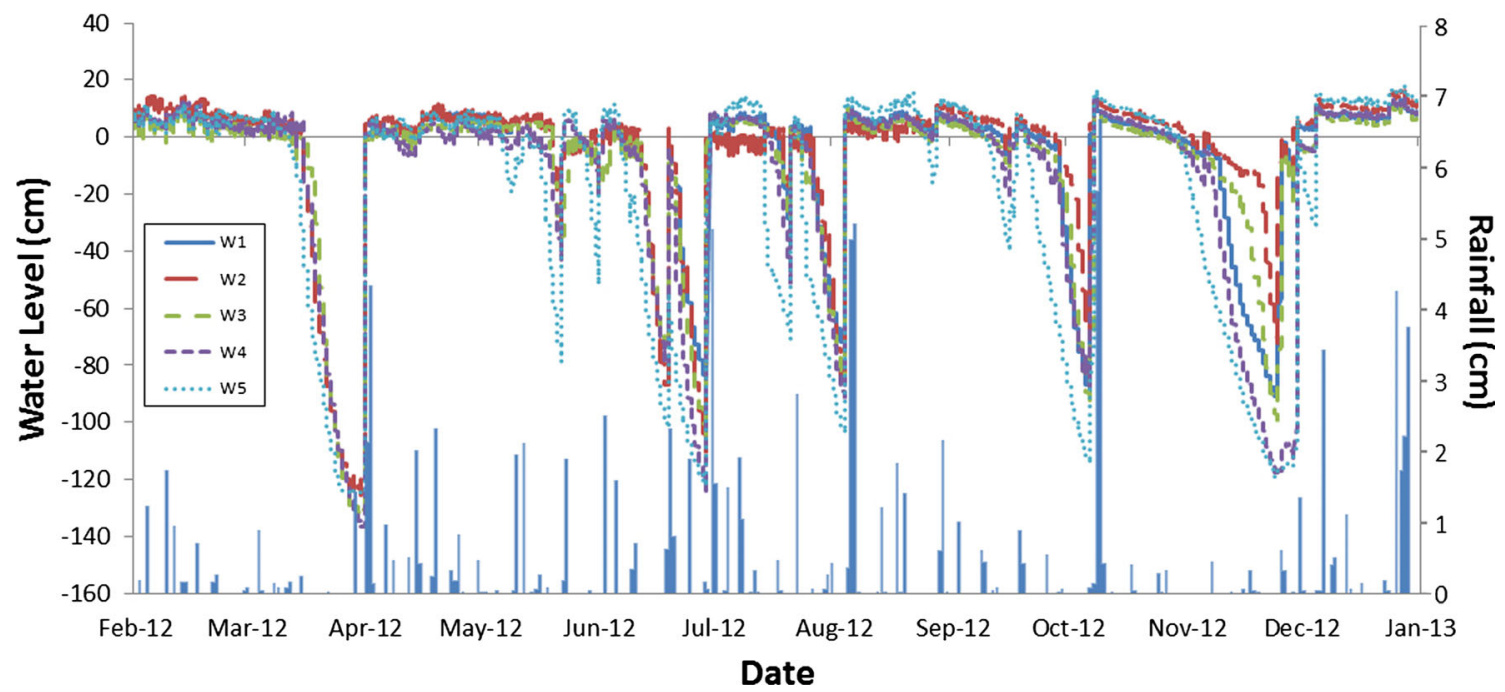

Fig. 6 Water level as recorded by five $1.5 \mathrm{~m}$ loggers placed in $1.5 \mathrm{~m}$ wells (W1 through W5) at the Charles City Wetland in Charles City County, Virginia, USA from 22 February, 2012 to 21 January, 2013.

$\mathrm{CCW} \mathrm{CH} 4$ flux shows no significant relationship with $\mathrm{OM}$ loading rate, suggesting that if excess nutrients and enhanced primary productivity are enhancing methane production, then the increase is being cancelled out by concomitant $\mathrm{CH}_{4}$ oxidation. This result contrasts with findings from another study in which addition of OM to intact wetland soil cores led to higher rates of potential net methane emissions compared to controls (Ballantine et al. 2014). Ballantine et al. 2014 found that adding $\mathrm{OM}$ created conditions more favorable for methanogenesis through an indirect mechanism - by increasing water retention. At the $\mathrm{CCW}, \mathrm{OM}$ additions may have had the opposite effect on soil moisture because of a slight mounding effect as described earlier. Our data from the relatively drier months of May and July show weak (r-squared of 0.16 and 0.14 , respectively), marginally significant $(p<0.09$ and $p<0.11$, respectively) relationships between SVWC and $\mathrm{OM}$ loading rate. Increasing soil $\mathrm{C}$ by adding $\mathrm{OM}$ does not
Positive values indicate standing water. Overlaid precipitation data are from a station in nearby James City County, Virginia (National Climate Data Center)

necessarily provide additional $\mathrm{C}$ substrate for methanogens, but it may alter methane production and/or oxidation because of indirect hydrologic effects. Heavy OM addition may elevate the soil surface allowing for more oxic conditions (our study), or conversely, it may enhance water holding capacity facilitating anoxia (Ballantine et al. 2014).

The OM gradient at the $\mathrm{CCW}$ does not incorporate a test of the effects of different OM types and results of other studies conflict as to whether or not OM quality matters. Ballentine et al. (2015) found that several OM sources (straw, topsoil, straw+biochar, biochar) led to statistically indistinguishable increases in potential net $\mathrm{CH}_{4}$ emissions over control. In contrast Morrissey et al. (2013) found added leaf litter led to increased $\mathrm{CH}_{4}$ flux, but added compost did not. It is noteworthy that our results are consistent with one of the conclusions reached by Morrissey et al. (2013): that adding compost increases $\mathrm{CO}_{2}$ flux, but not $\mathrm{CH}_{4}$ flux.
Fig. 7 Linear regressions of mean $( \pm \mathrm{SE})$ total carbon in top $10 \mathrm{~cm}$ of soil in 2011 across organic matter amendment plots at the Charles City Wetland in Charles City County, Virginia, USA. 2005 data from Bailey et al. (2007)

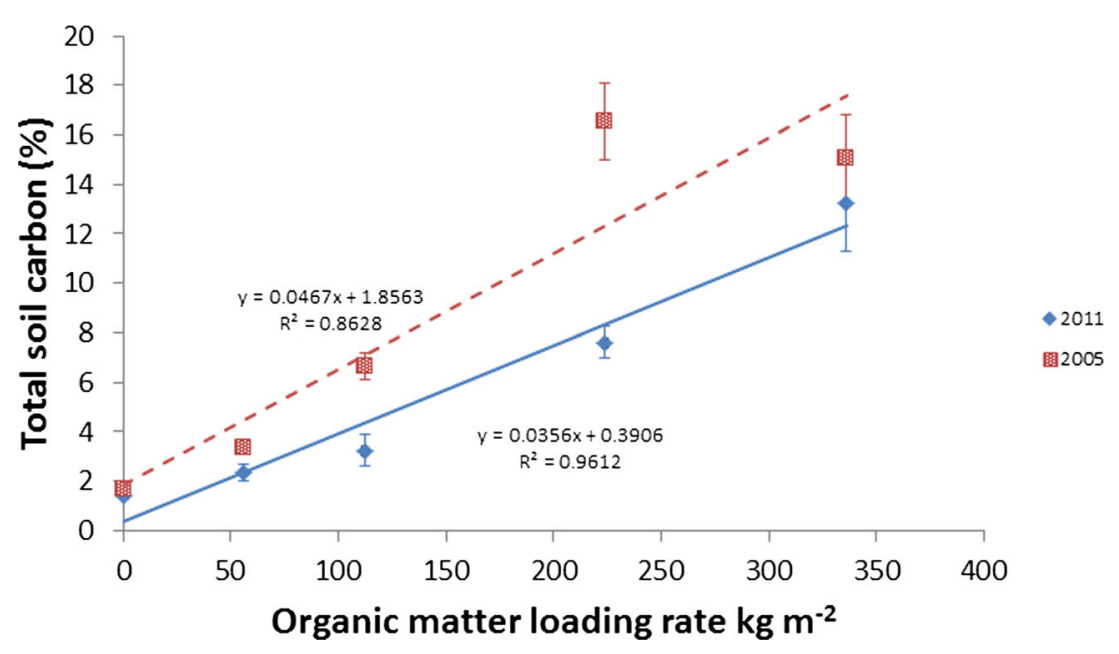


Table 3 Review of methane $\left(\mathrm{CH}_{4}\right)$ emissions rates in $\mathrm{kg} \mathrm{CH}_{4}-\mathrm{C} \mathrm{ha}^{-1} \mathrm{y}^{-1}$ from natural and restored forested wetlands of the Southeastern United States

\begin{tabular}{llll}
\hline $\mathrm{CH}_{4}$ flux & Location & Type & Reference \\
\hline 554 & Newport News Swamp, Va. & Natural & (Wilson et al. 1989) \\
427 & Newport News Swamp, Va. & Natural & (Wilson et al. 1989) \\
311 & Ogeechee River, Ga. (west) & Natural & (Pulliam 1993) \\
297 & Okeefenokee Swamp, Ga. & Natural & (Flebbe 1982) \\
262 & Creeping Swamp, NC & Natural & (Mulholland 1981) \\
107 & Timberlake Restoration Preserve, NC & Restored & (Morse et al. 2012) \\
92 & Ogeechee River, Ga. (east) & Natural & (Pulliam 1993) \\
72 & Palmetto Peartree Preserve, NC & Natural & (Morse et al. 2012) \\
31 & Charles City Wetland, Va. & Restored & This study \\
14 & Timberlake Restoration Preserve, NC & Restored & (Morse et al. 2012) \\
0.5 & Timberlake Restoration Preserve, NC & Restored & (Morse et al. 2012) \\
\hline
\end{tabular}

\section{Climate Impacts of Created/Restored Wetlands}

The radiative forcing switchover time (Frolking et al. 2006) for $\mathrm{CCW}$ is uncertain because of high variability in NEE (Bailey 2006) and $\mathrm{CH}_{4}$ flux data (this study). Furthermore, for this analysis we must assume that $\mathrm{CH}_{4}$ emissions and NEE will remain constant over many decades. In reality NEE is likely to be dynamic over at least several decades of succession (Odum 1969). The temporal mismatch in our input data-NEE data from 2006 and $\mathrm{CH}_{4}$ data from 2012-is a potential source of error. If the $\mathrm{CCW}$ ecosystem has become a more efficient $\mathrm{C}$ sink over the 6-year period as trees have matured, then we may be overestimating radiative forcing switchover time. Therefore it would take a long-term monitoring approach to improve the certainty of radiative forcing switchover time for the CCW. But despite the shortcomings mentioned above, we may conclude that $\mathrm{CCW}$ has a relatively short radiative forcing switchover time due to its low $\mathrm{CH}_{4}$ flux. Importantly, CCW will likely become a net GHG sink more quickly than at least six out of eight wetlands analyzed by Neubauer (2014).

While we may be tempted to generalize the results from $\mathrm{CCW}$ to all other created/restored wetlands, we caution that wetlands are diverse, idiosyncratic ecosystems, especially those which have undergone intense transformations, as the $\mathrm{CCW}$ has. Many factors determine how much $\mathrm{CH}_{4}$ is produced and emitted, including the quality of any added OM, type of plant cover, productivity and hydrology. Since all data were collected from a single site amended with a single OM type (compost), our conclusions may or may not apply to other created/restored wetlands but our analytical approach for assessing radiative forcing switchover time should prove useful.

\section{Temporal Changes at Charles City Wetland}

We found micro-elevational differences between plots, described above, to be less pronounced in 2012 compared to conditions in 2005 reported by Bailey et al. (2007). The relationship between OM loading rate and elevation was far weaker in 2012 (see Table 4), which could be the result of settling or subsidence due to more rapid OM oxidation in elevated, high-OM plots. The higher rates of soil respiration that we and Bailey et al. (2007) detected coming from higher $\mathrm{OM}$ plots are consistent with an oxidation-subsidence explanation for the loss of elevation, as is the difference in total soil C between 2005 and 2012 we observed (see Fig. 7).

Our annual soil respiration budget does not fully account for the soil $\mathrm{C}$ losses in the 112 and $224 \mathrm{~kg} \mathrm{~m}^{-2}$ plots we observe between 2005 and 2012, which were approximately 3.4 and $8.9 \% \mathrm{C}$, respectively (Fig. 7), corresponding to respective losses of 0.8 and $1.6 \mathrm{~kg} \mathrm{C} \mathrm{m}^{-2} \mathrm{y}^{-1}$ over 7 years from the top $10 \mathrm{~cm}$ of soil. These loss rates are two to four times greater than our estimated annual soil respiration loss from these plots: 0.42 and $0.49 \pm 0.032 \mathrm{~kg} \mathrm{CO}_{2}-\mathrm{C} \mathrm{m}^{-2} \mathrm{y}^{-1}$ respectively, but bracket estimates of approximately 1.3 and $1.4 \mathrm{~kg}$ $\mathrm{CO}_{2}-\mathrm{C} \mathrm{m}^{-2} \mathrm{y}^{-1}$ respectively made by Bailey (2006). The relatively wet conditions in 2012 relative to 2005 (Table 4) could explain why we found soil respiration to be lower than Bailey
Table 4 Comparison of microtopographic and growing season hydrologic conditions at the Charles City Wetland in Charles City County, Virginia between 2005 (Bailey et al.) and 2012 (this study)

\begin{tabular}{|c|c|c|c|c|c|}
\hline \multirow[t]{2}{*}{ Year } & \multicolumn{2}{|c|}{ Rainfall (Apr. - Oct.; cm) ${ }^{b}$} & \multicolumn{3}{|c|}{ Elevation across OM loading rates } \\
\hline & Total & Depart. from normal & Range (cm) & Lin. reg. r-squared & Lin. reg. p-value \\
\hline 2005 & 69 & -7.5 & 11 & 0.55 & $<0.001$ \\
\hline 2012 & 82 & +5.7 & 6 & 0.17 & $<.05$ \\
\hline
\end{tabular}


(2006) since saturation inhibits soil respiration. The CCW was relatively wet during the 2012 growing season when it received $82 \mathrm{~cm}$ of rain $(7.5 \%$ above mean; National Climatic Data Center; Lawrimore et al. 2011) and held ponded water $52 \%$ of the time. This contrasts with conditions during the 2005 growing season when the CCW received $10 \%$ less rainfall than average (National Climatic Data Center; Lawrimore et al. 2011) and water was ponded just $25 \%$ of the time (Bailey et al. 2007). We also suspect that the rate of $\mathrm{C}$ loss has decreased as soil $\mathrm{C}$ content decreased leaving more recalcitrant materials over the past 7 years. Some $\mathrm{C}$ loss may also be due to leaching of dissolved OM into lower soil layers and/ or transport of particulate OM during floods.

The overall seasonal pattern in soil $\mathrm{CO}_{2}$ flux we observe is similar to what Bailey (2006) reported from the CCW for $2005 / 2006$ with peak respiration of greater than $400 \mathrm{mg} \mathrm{m}^{-2} \mathrm{~h}^{-1}$ during summer dry periods and low $\mathrm{CO}_{2}$ flux of less than $100 \mathrm{mg} \mathrm{m}^{-2} \mathrm{~h}^{-1}$ during wet winter months. The positive relationship between $\mathrm{CO}_{2}$ flux and soil $\mathrm{OM}$ loading rate is also consistent with Bailey's (2006) results.

\section{Conclusions}

We found little evidence to suggest that added composted yard waste increases $\mathrm{CH}_{4}$ emissions from $\mathrm{CCW}$ a decade after restoration. $\mathrm{CH}_{4}$ emissions are only significant when soils are warm and water levels and soil moisture are high. Even when $\mathrm{CH}_{4}$ flux is at its greatest magnitude, it still represents a relatively modest contribution to radiative forcing compared to soil $\mathrm{CO}_{2}$ flux.

Yet even if $\mathrm{CCW}$ were to produce no $\mathrm{CH}_{4}$, it would still be a net $\mathrm{CO}_{2}$ source at high $\mathrm{OM}$ loading rates because of negative NEE (Bailey 2006), at least until the excess OM is respired. Therefore the addition of high levels of OM $\left(>112 \mathrm{~kg} \mathrm{~m}^{-2}\right)$ to created wetlands may be detrimental to greenhouse gas budgets due to enhanced soil respiration. At the $\mathrm{CCW}$, heavy additions of OM decompose over time while adding little in the way of tangible productivity increases (Bailey et al. 2007) or soil geochemistry improvement (Bruland and Richardson 2009), not to mention incurring greater material transport and associated construction costs.

\footnotetext{
Acknowledgments We appreciate the help of Jonathan Bills, who provided critical assistance with site instrumentation and field sampling as well as sample processing and analysis. Wes Willis also contributed greatly to the water and soil processing effort. Ashley Helton and Emily Bernhardt gave valuable advice and training in static chamber design and gas sampling and Todd Smith assisted with chamber construction. Jim Perry, Lee Daniels, David Bailey and Leo Snead provided valuable insight into the site history and scope of previous investigations. Darmawan Prasadojo assisted with programming an Excel Visual Basic macro designed to wrangle data output from the gas chromatograph. Helpful comments from an anonymous reviewer and an editor for Wetlands greatly improved the manuscript. We thank Ann and Jay Kinney for graciously allowing us to use of their driveway to access the site. This work was
}

supported by the Peterson Family Foundation in collaboration with Wetland Studies and Solutions Inc., and the Duke Wetland Center Endowment

\section{References}

Bailey DE (2006) Wetland vegetation dynamics and ecosystem gas exchange in response to organic matter loading rates. Dissertation, College of William and Mary

Bailey D, Perry J, Daniels W (2007) Vegetation dynamics in response to organic matter loading rates in a created freshwater wetland in southeastern Virginia. Wetlands 27:936-950

Ballantine KA, Lehmann J, Schneider RL, Groffman PM (2014) Tradeoffs between soil-based functions in wetlands restored with soil amendments of differing lability. Ecological Applications 140625210517000. doi:10.1890/13-1409.1

Bergschneider CR (2005) Determining an appropriate organic matter loading rate for a created coastal plain forested wetland. MS Thesis, Virginia Polytechnic Institute and State University

Bloom AA, Palmer PI, Fraser A et al (2010) Large-scale controls of methanogenesis inferred from methane and gravity spaceborne data. Science 327:322-325. doi:10.1038/nchem.467

Bocock K (1964) Changes in the amounts of dry matter, nitrogen, carbon and energy in decomposing woodland leaf litter in relation to the activities of the soil fauna. Journal of Ecology 52:273-284

Bridgham SD, Patrick Megonigal J, Keller JK et al (2006) The carbon balance of North American wetlands. Wetlands 26:889. doi:10. 1672/0277-5212(2006)26[889:TCBONA]2.0.CO;2

Bridgham SD, Moore TR, Richardson CJ, Roulet NT (2014) Errors in greenhouse forcing and soil carbon sequestration estimates in freshwater wetlands: a comment on Mitsch et al. (2013). Landscape Ecology 29:1481-1485. doi:10.1007/s10980-014-0067-2

Bruland G, Richardson C (2004) Hydrologic gradients and topsoil additions affect soil properties of Virginia created wetlands. Soil Science Society of America Journal 68:2069-2077

Bruland G, Richardson C (2009) Microbial and geochemical responses to organic matter amendments in a created wetland. Wetlands 29: $1153-1165$

Daniels W, Perry JE, Whittecar RG et al (2005) Effects of soil amendments and other practices upon the success of the Virginia department of transportation's non-tidal wetland mitigation efforts. Virginia Transportation Research Council, Charllottesville

Despres AD (2004) Hydrologic variations within created and natural wetlands in southeastern Virginia. MS Thesis, Old Dominion University

Flebbe PA (1982) Biogeochemistry of carbon, nitrogen, and phosphorus in the aquatic subsystem of selected Okefenokee Swamp sites. Dissertation, University of Georgia

Frolking S, Roulet N, Fuglestvedt J (2006) How northern peatlands influence the earth's radiative budget: sustained methane emission versus sustained carbon sequestration. Journal of Geophysical Research 111:G01008. doi:10.1029/2005JG000091

Goslee SC, Urban DL (2007) The ecodist package for dissimilarity-based analysis of ecological data. J Stat Softw 22(7):1-19

JMP $^{\circledR}$, Version 13. SAS Institute Inc., Cary, NC, 1989-2013

Lal R (2005) Forest soils and carbon sequestration. Forest Ecology and Management 220:242-258. doi:10.1016/j.foreco.2005.08.015

Lawrimore JH, Menne MJ, Gleason BE et al (2011) An overview of the global historical climatology network monthly mean temperature data set, version 3. Journal of Geophysical Research 116:D19121. doi:10.1029/2011JD016187

Livingston GP, Hutchinson GL (1995) Enclosure-based measurement of trace gas exchange: applications and sources of error. In: Matson PA, 
Harriss RC (eds) Biogenic trace gases: measuring emissions from soil and water. Wiley-Blackwell, Cambridge, MA, pp 14-51

Lloyd J, Taylor J (1994) On the temperature dependence of soil respiration. Functional Ecology 8:315-323

Mitsch WJ, Gosselink JG (2007) Wetlands, 4th edn. Wiley, Hoboken

Mitsch WJ, Bernal B, Nahlik AM et al (2013) Wetlands, carbon, and climate change. Landscape Ecology 28:583-597. doi:10.1007/ s10980-012-9758-8

Morrissey EM, Berrier DJ, Neubauer SC, Franklin RB (2013) Using microbial communities and extracellular enzymes to link soil organic matter characteristics to greenhouse gas production in a tidal freshwater wetland. Biogeochemistry 117:473-490

Morse J, Ardon M, Bernhardt ES (2012) Greenhouse gas fluxes in southeastern US coastal plain wetlands under contrasting land uses. Ecological Applications 22:264-280

Mulholland PJ (1981) Organic carbon flow in a swamp-stream ecosystem. Ecological Monographs 51:307-322

Myhre G, Shindell D, Bréon F-M et al (2013) Anthropogenic and natural radiative forcing. In: Stocker TF, Qin D, Plattner G-K et al (eds) Climate change 2013: the physical science basis. Cambridge University Press, Cambridge and New York, pp 1-124

Neubauer SC (2014) On the challenges of modeling the net radiative forcing of wetlands: reconsidering Mitsch et al. 2013. Landscape Ecology 29:571-577. doi:10.1007/s10980-014-9986-1

Neubauer SC, Megonigal JP (2015) Moving beyond global warming potentials to quantify the climatic role of ecosystems. Ecosystems. doi:10.1007/s10021-015-9879-4

Odum EP (1969) The strategy of ecosystem development. Science 164: 262-270. doi:10.1126/science.164.3877.262
Pulliam WM (1993) Carbon dioxide and methane exports from a southeastern floodplain swamp. Ecological Monographs 63:29-53

R Core Team (2014) R: a language and environment for statistical computing. R Foundation for Statistical Computing, Vienna, Austria. http://www.R-project.org/

Schlesinger WH (1997) Biogeochemistry: an analysis of global change, 2nd edn. Academic, San Diego

Stauffer A, Brooks R (1997) Plant and soil responses to salvaged marsh surface and organic matter amendments at a created wetland in central Pennsylvania. Wetlands 17:90-105

Sutton-Grier AE, Ho M, Richardson CJ (2009) Organic amendments improve soil conditions and denitrification in a restored riparian wetland. Wetlands 29:343-352. doi:10.1672/08-70.1

Weishampel P, Kolka R (2008) Measurement of methane fluxes from terrestrial landscapes using static, non-steady state enclosures. In: Hoover CM (ed) field measurements for forest carbon monitoring, Springer, pp 163-170

Whalen SC (2005) Biogeochemistry of methane exchange between natural wetlands and the atmosphere. Environmental Engineering Science 22:73-93

Whittecar GR, Daniels WL (1999) Use of hydrogeomorphic concepts to design created wetlands in southeastern Virginia. Geomorphology 31:355-371. doi:10.1016/S0169-555X(99) 00081-1

Wilson JO, Crill PM, Bartlett KB et al (1989) Seasonal variation of methane emissions from a temperate swamp. Biogeochemistry 8 : 55-71. doi:10.1007/BF02180167

Zedler J, Callaway J (1999) Tracking wetland restoration: do mitigation sites follow desired trajectories? Restoration Ecology 7:69-73. doi: 10.1046/j.1526-100X.1999.07108.x 